$$
\text { CONF. } 961202 \cdot-64
$$

\title{
KEY MICROSTRUCTURES CONTROLLING THE MECHANICAL PROPERTIES OF TWO-PHASE TIAI ALLOYS WITH LAMELLAR STRUCTURES
}

\author{
C. T. LIU, P. J. MAZIASZ, and J. L. WRIGHT
}

Metals and Ceramics Division, Oak Ridge National Laboratory, Oak Ridge, TN 37831-6115, USA

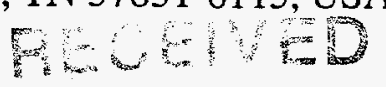

ABSTRACT

FFR 121997.

The objective of this study is to identify key microstructural parameters Afict cotntol the mechanical properties of two-phase $\gamma$-TiAl alloys with lamellar structures. TiAl alloys with the base composition of Ti-47Al-2Cr-2 $\mathrm{Nb}$ (at. \%) were prepared by arc melting and drop casting, followed by hot extrusion at temperatures above the $\alpha$-transus temperature, $T_{\alpha}$. The hot extruded materials were then heat treated at various temperatures above and below $T_{\alpha}$ in order to control microstructural features in these lamellar structures. The mechanical properties of these alloys were determined by tensile testing at temperatures to $1000^{\circ} \mathrm{C}$. The tensile elongation at room temperature is strongly dependent on grain size, showing an increase in ductility with decreasing grain size. The strength at room and elevated temperatures is sensitive to interlamellar spacing, showing an increase in strength with decreasing lamellar spacing. Hall-Petch relationships hold well for the yield strength at room and elevated temperatures and for the tensile elongation at room temperature. Tensile elongations of about $5 \%$ and yield strengths around $900 \mathrm{MPa}$ are achieved by controlling both colony size and interlamellar spacing. The mechanical properties of the TiAl alloys with controlled lamellar structures produced directly by hot extrusion are much superior to those produced by conventional thermomechanical treatments.

\section{INTRODUCTION}

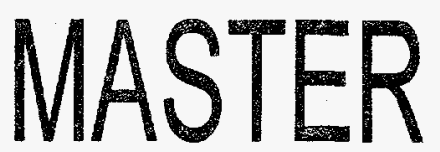

The mechanical properties of two-phase TiAl alloys are sensitive to both alloy composition and microstructure [1-5]. The two common types of microstructure formed in TiAl alloys are lamellar structures generally observed in cast conditions and duplex structures in thermomechanically treated conditions. The lamellar structures with coarse grain sizes $(>500 \mu \mathrm{m})$ exhibit adequate fracture toughness but poor tensile ductility at ambient temperatures; on the other hand, the duplex structures with fine grain sizes $(<50 \mu \mathrm{m})$ show adequate tensile ductility but poor fracture toughness. For the past decade or so, considerable effort has been devoted to microstructural design of two-phase TiAl alloys with balanced properties [1-6].

The objective of this study is to identify the key microstructural parameters controlling the mechanical properties of two-phase TiAl alloys at room and elevated temperatures. In this study, $\mathrm{Ti}-47 \mathrm{Al}-2 \mathrm{Cr}-2 \mathrm{Nb}$ (at. \%) was selected as the base alloy composition, and minor alloying additions at levels $\leq 1 \%$ were added for microstructural control. Since lamellar structures generally have good strength and creep resistance at high temperatures $[3,7,8]$, the present study has been focused on understanding and controlling microstructural features in lamellar structures. The $\mathrm{Al}$ concentration in the alloys varied from 46 to 48 at. $\%$ for adjusting the amount of the $\alpha$ phase relative to the $\gamma$ phase. The microstructural parameters such as grain size (or colony size), lamellar spacings, and grain-boundary equiaxed phases were controlled by material processing and heat treatment, and characterized by optical and transmission electron microscopy (TEM). Some preliminary data obtained earlier have been reported elsewhere [9]. Our studies have revealed that the average grain size and the interlamellar spacing are the key microstructural parameters for controlling the tensile properties at room and elevated temperatures. 


\section{DISCLAIMER}

Portions of this document may be illegible in electronic image products. Images are produced from the best available original document. 
Alloy No.

Alloy Composition

Hot Extrusion (at. \%)

Temperature *

TIA-20

TIA-21

Ti-47Al-2Cr-2Nb-0.15B

Ti-47Al-2Cr-1.8Nb-0.2W-0.15B

$\mathrm{T}_{1}, \mathrm{~T}_{2}$

TLA-23

Ti-46Al-2Cr-2Nb-0.15B

TIA-24

Ti-48Al-2Cr-2Nb-0.15B

$\mathrm{T}_{2}$

TIA- 25

Ti-46Al-2Cr-1.8Nb-0.2W-0.15B

$\mathrm{T}_{2}$

$* \mathrm{~T}_{2}>\mathrm{T}_{1}>\mathrm{T}_{\alpha}$

\section{EXPERIMENTAL PROCEDURES}

Table 1 lists the alloy compositions and hot extrusion conditions for the TiAl alloys used in this study. The base composition of Ti- $47 \mathrm{Al}-2 \mathrm{Cr}-2 \mathrm{Nb}$ (at. \%) was modified with additions of $0.15 \mathrm{~B}$ and $0.2 \mathrm{~W}$. Boron and tungsten were added for refining the lamellar structure and improving its stability [10-12]. Tungsten was also reported to have the beneficial effect of enhancing high-temperature properties [3]. The five alloys containing 46-48 at.\% Al were prepared by arc melting and drop casting into a copper mold, using high-purity charge materials. The alloy ingots were then canned in Mo billets and hot extruded at $T_{1}$ and $T_{2}$, where $T_{2}>T_{1}>T_{\alpha}\left(T_{\alpha} \approx 1320^{\circ}\right.$ $\mathrm{C}$ for $\mathrm{Ti}-47 \mathrm{Al}-2 \mathrm{Cr}-2 \mathrm{Nb}$ alloy) [2].

The hot extruded alloys were heat treated for $2 \mathrm{~h}$ at temperatures from 900 to $1350^{\circ} \mathrm{C}$ in vacuum. Buttonhead-type tensile specimens (gage section: $9.53 \mathrm{~mm}$ length $\times 3.18 \mathrm{~mm}$ diameter) were prepared from heat-treated materials by electro-discharge machining, followed by surface grinding. The specimens were mechanically polished to remove surface scratches (using 00-grade $\mathrm{SiC}$ papers) prior to testing. Tensile tests were performed on an Instron testing machine at temperatures to $1000^{\circ} \mathrm{C}$ in air at a cross-head speed of $0.25 \mathrm{~cm} / \mathrm{min}$. (strain rate $4.4 \times 10^{-3} / \mathrm{s}$ ). In order to calibrate the small strains obtained at room temperature and $300^{\circ} \mathrm{C}$, tensile strains measured from the strip chart were corrected on the basis of strain measurement using a clip-on Instron strain gage at room temperature. The tensile strains at 800 and $1000^{\circ} \mathrm{C}$ were determined mainly from broken specimens.

Microstructural features in selected specimens were studied by optical microscopy and by TEM. Metallographic samples were polished on a syntron and etched in a solution of $100 \mathrm{ml} \mathrm{H}_{2} \mathrm{O}$, $8 \mathrm{HNO}_{3}$, and $0.5 \mathrm{HF}$ to reveal lamellar structures. TEM disks were prepared by twin-jet electropolishing in a solution of $6 \%$ perchloric acid, $60 \%$ methanol, $33.5 \%$ butyl cellusolve, and $0.5 \%$ glycerin at a temperature of $-20^{\circ} \mathrm{C}$ and at $32 \mathrm{~V}$. Thinned foils were then examined using Philips CM12 (120 kV), Philips CM200/FEG (200 kV), and Philips CM30 (300 kV) electron microscopes.

\section{RESULTS AND DISCUSSION}

All the alloys were successfully hot extruded above $T_{\alpha}$ at $T_{1}$ and $T_{2}$ without difficulty. The hot extrusion above $T_{\alpha}$ resulted in lamellar structures with extremely fine colony sizes $(22-33 \mu \mathrm{m})$. The hot extrusion at $T_{1}$ produced near fully lamellar structures, with some equiaxed and elongated 
$\gamma$ grains existing along colony boundaries. On the other hand, the hot extrusion at $\mathrm{T}_{2}$ resulted in a much smaller amount of $\gamma$ grains at those boundaries. Figure 1 shows a close to fully lamellar structure produced by hot extrusion of TIA-23 at $\mathrm{T}_{2}$. This alloy was also stress-relieved for $2 \mathrm{~h}$ at $900^{\circ} \mathrm{C}$ (after extrusion), which caused no change in optical microstructure. In order to vary grain size and lamellar spacings, the hot extruded alloys were heat treated close to $T_{\alpha}$ for $2 \mathrm{~h}$. As shown in Fig 2, the heat treatment at $1320^{\circ} \mathrm{C}\left(\approx \mathrm{T}_{\alpha}\right)$ caused no significant change in grain size, but the heat treatment at $1350^{\circ} \mathrm{C}$ resulted in a sharp increase. The variation in grain size by heat treatment of TIA-20, $-21,-21-2$, and -25 is given in Table 2 .

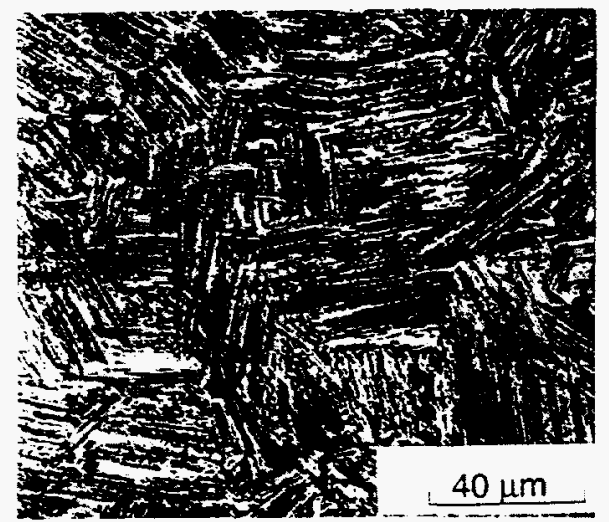

Fig. 1. TIA-23 hot extruded at $\mathrm{T}_{2}$ and heat treated for $2 \mathrm{~h}$ at $900^{\circ} \mathrm{C}$
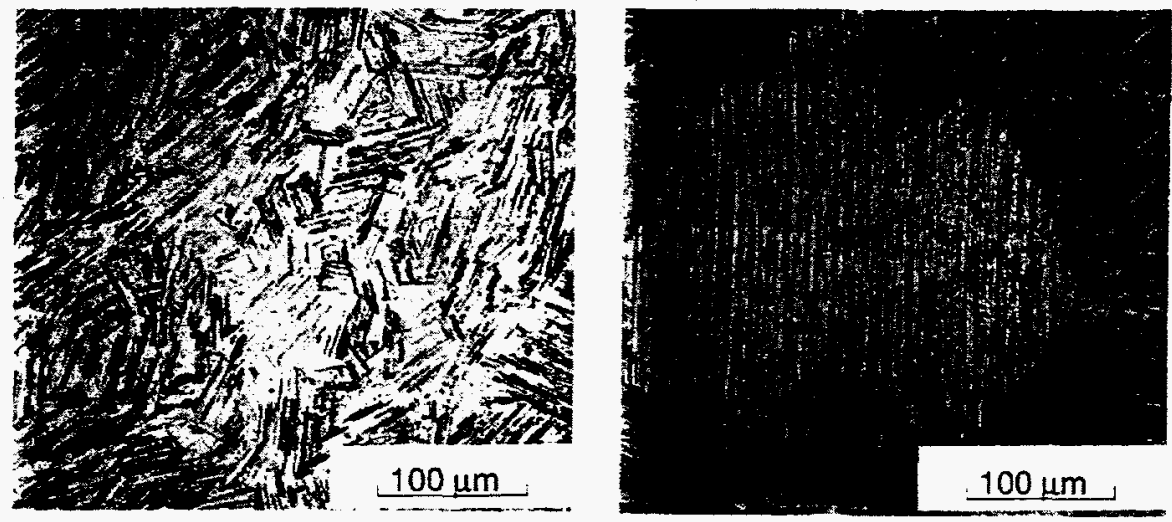

Fig. 2. TIA-20 hot extruded at $T_{1}$, (a) heat treated for $2 \mathrm{~h}$ at $1320^{\circ} \mathrm{C}$ and (b) heat treated for $2 \mathrm{~h}$ at $1350^{\circ} \mathrm{C}$

Table 2. Quantitative Lamellar Microstructural Data on Hot Extruded and Heat Treated TiAl Alloys

\begin{tabular}{|c|c|c|c|c|}
\hline Alloy/HT & $\begin{array}{l}\text { Compositions } \\
\text { (at. \%) }\end{array}$ & $\begin{array}{l}\text { Interlamellar } \\
\text { Spacing (nm) }\end{array}$ & $\begin{array}{c}\gamma \text {-Platelet } \\
\text { Width }(\mathrm{nm}) \\
\end{array}$ & $\begin{array}{c}\text { Grain Size } \\
(\mu \mathrm{m})\end{array}$ \\
\hline \multicolumn{5}{|c|}{ Hot-Extruded at $T_{1}$} \\
\hline TIA-20 & $47 \mathrm{Al}-2 \mathrm{Cr}-2 \mathrm{Nb}-0.15 \mathrm{~B}$ & & & \\
\hline $2 \mathrm{~h} / 900^{\circ} \mathrm{C}$ & & 225 & $95-870$ & \\
\hline $2 \mathrm{~h} / 1320^{\circ} \mathrm{C}$ & & 440 & $160-1250$ & 33 \\
\hline $2 \mathrm{~h} / 1350^{\circ} \mathrm{C}$ & & & & 182 \\
\hline TIA-21 & $47 \mathrm{Al}-2 \mathrm{Cr}-1.8 \mathrm{Nb}-0.2 \mathrm{~W}-0.15 \mathrm{~B}$ & & & \\
\hline $2 \mathrm{~h} / 900^{\circ} \mathrm{C}$ & & 160 & $74-635$ & \\
\hline $2 \mathrm{~h} / 1320^{\circ} \mathrm{C}$ & & 300 & $290-1100$ & 31 \\
\hline $2 \mathrm{~h} / 1350^{\circ} \mathrm{C}$ & & & & 150 \\
\hline \multicolumn{5}{|c|}{ Hot-Extruded at $T_{2}$} \\
\hline TIA-21-2. & $47 \mathrm{Al}-2 \mathrm{Cr}-1.8 \mathrm{Nb}-0.2 \mathrm{~W}-0.15 \mathrm{~B}$ & & & \\
\hline $2 \mathrm{~h} / 900^{\circ} \mathrm{C}$ & & 141 & $40-750$ & 25 \\
\hline $2 \mathrm{~h} / 1320^{\circ} \mathrm{C}$ & & & & 35 \\
\hline $2 \mathrm{~h} / 1350^{\circ} \mathrm{C}$ & & & & 99 \\
\hline TIA-25 & $46 \mathrm{Al}-2 \mathrm{Cr}-1.8 \mathrm{Nb}-0.2 \mathrm{~W}-0.15 \mathrm{~B}$ & & & \\
\hline $2 \mathrm{~h} / 900^{\circ} \mathrm{C}$ & & 105 & $21-520$ & 26 \\
\hline $\begin{array}{l}2 \mathrm{~h} / 1320^{\circ} \mathrm{C} \\
2 \mathrm{~h} / 1350^{\circ} \mathrm{C}\end{array}$ & & & & $\begin{array}{l}135 \\
148\end{array}$ \\
\hline
\end{tabular}


Microstructural features in TIA-20 and -21 extruded at $T_{1}$ and TIA-21-2 and TIA-25 extruded at $\mathrm{T}_{2}$ were examined by TEM after stress relieved for $2 \mathrm{~h}$ at $900^{\circ} \mathrm{C}$. Figure 3 shows the fine, regular lamellar structures observed within colonies in TIA-20 and 21. The lamellar spacings were carefully measured, and their results are summarized in Table 2.
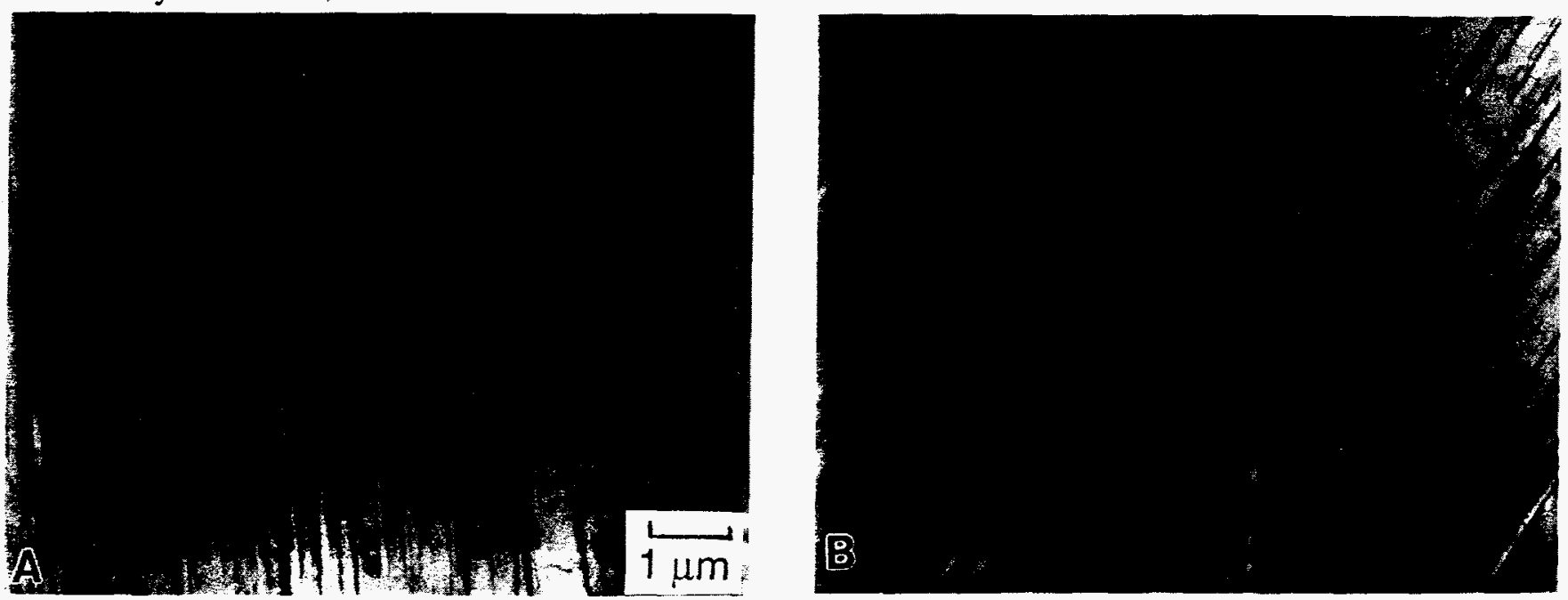

Fig. 3. Lamellar structures within colonies in as-extruded (a) TIA-20 and (b) TIA-21, both after a stress-relief heat treatment for $2 \mathrm{~h}$ at $900^{\circ} \mathrm{C}$

The average interlamellar spacing, measured to include both $\gamma$ and $\alpha_{2}$ platelets, varies from 105 to $440 \mathrm{~nm}$, with the finest spacing for TIA-25 in the hot-extruded and stress-relieved condition. Because of the fine interlamellar spacing in the as-extruded materials. the ratio of $\gamma$ to $\alpha_{2}$ platelets is close to $1: 1$, indicating only a few $\gamma / \gamma$ boundaries. Figure 4 compures the microstructure of the lamellar structures in TIA-21 hot extruded at $\mathrm{T}_{!}$and $\mathrm{T}_{2}$. The extrusion at $\mathrm{T}_{1}$ resulted in about $10-$ $20 \%$ volume fraction of equiaxed and elongated $\gamma$ in intercolony grain regions, whereas the extrusion at $\mathrm{T}_{2}$ resulted in less than $10 \%$ intercolony $\gamma$ structures. This comparison suggests that, during the hot extrusion, the temperature of the extrusion billets (which were preheated to $T_{1}$ ) may have dropped to below $T_{\alpha}$, resulting in the formation of $\gamma$ along the $\alpha$ grain boundaries.
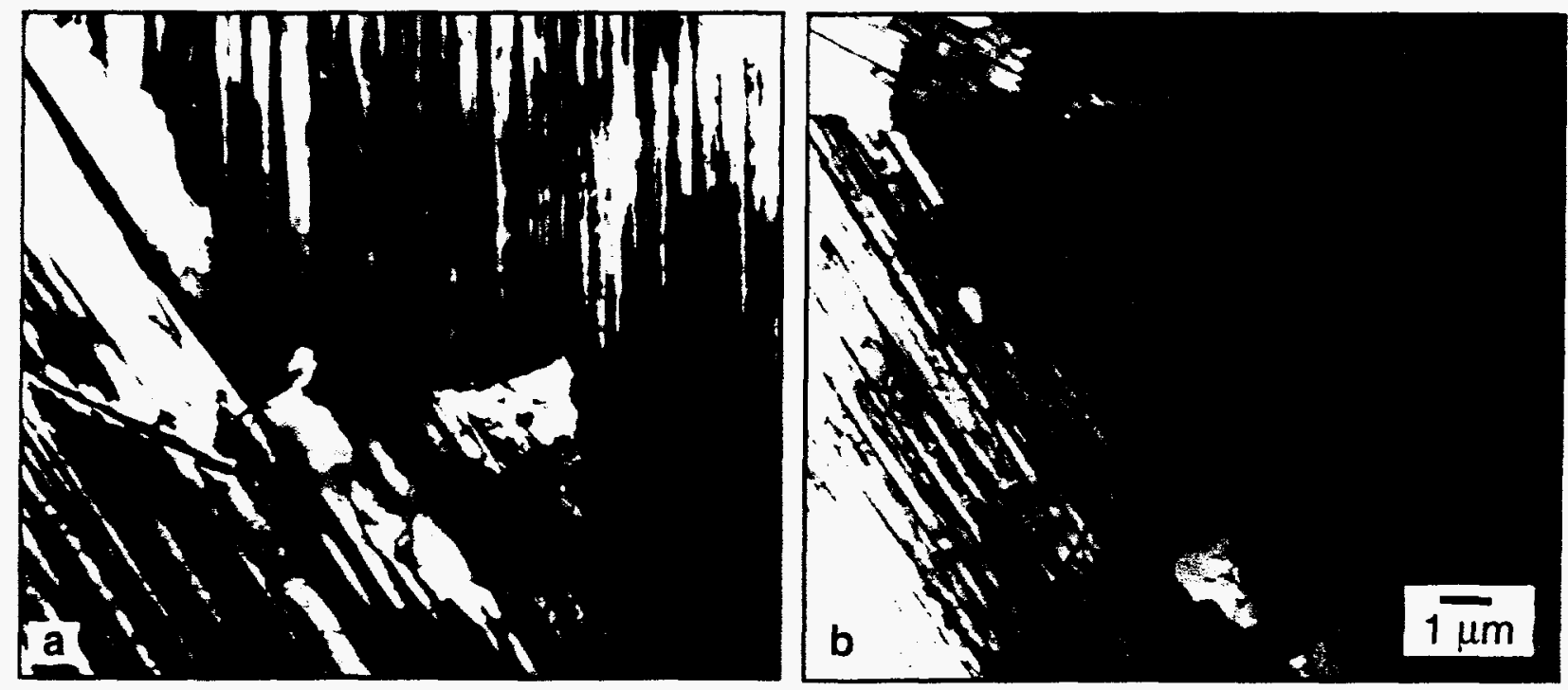

Fig. 4. Effect of hot extrusion temperature on intercolony structure in TIA-21
(a) extruded at $T_{2}$
(b) extruded at $T_{1}$ 
The tensile properties of these TIA alloys were determined at room temperature, 300,600 , 800 , and $1000^{\circ} \mathrm{C}$ in air. Figure 5 shows the effect of the $\mathrm{Al}$ concentration on the tensile properties of TIA-23 and -24 with the near fully lamellar structure produced by hot extrusion at $\mathrm{T}_{2}$. This plot indicates that TIA-23 with $46 \% \mathrm{Al}$ is substantially stronger at all test temperatures than TIA-24 with $48 \% \mathrm{Al}$. Two possible reasons to explain the better strength of TIA-23 are: (1) higher volume fraction of $\alpha_{2}$ platelets, and (2) finer interlamellar spacing in TIA-23. As indicated later, the second reason is considered to be the dominant one. The ductilities of the two alloys are similar, except that TIA-24 is more ductile at $800^{\circ} \mathrm{C}$. Figure 6 compares the tensile properties of TIA-25 (more optimized alloy composition and microstructure) with the advanced two-phase TiAl alloy, K-5 (Ti$46.5 \mathrm{Al}-2.1 \mathrm{Cr}-3 \mathrm{Nb}-0.2 \mathrm{~W}$, at. \%), prepared by casting and isothermal forging [5]. The comparison indicates that TIA-25 with a refined lamellar structure is much stronger and more ductile than K5. The superior tensile properties of TLA-25 are due to a combination of the fine colony size and the fine interlamellar spacing produced by hot extrusion, as indicated later.
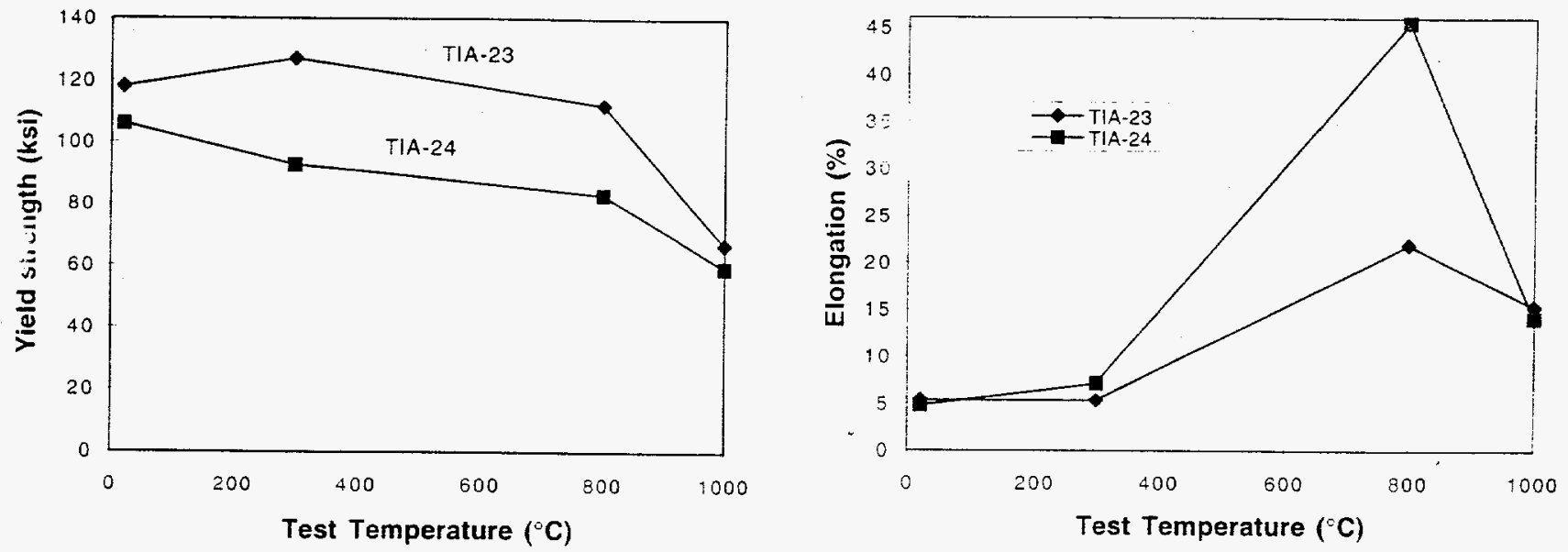

Fig. 5. Effect of Al concentration on tensile properties of TIA-23 (46\% Al) and TIA-24 (48\% Al)
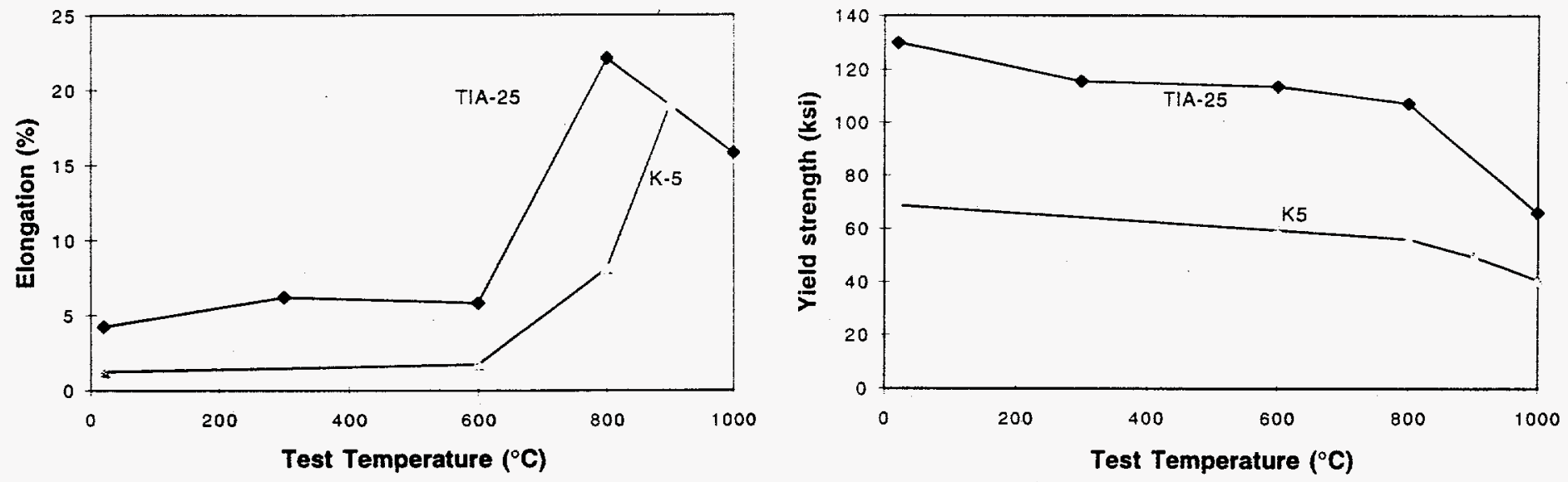

Fig. 6. Comparison of tensile properties of hot-extruded TIA-25 with thermomechanically treated alloy $\mathrm{K} 5$ (Ti-46.5Al-2.1Cr-3Nb-0.2W, at.\%) [5]

In order to identify key parameters, the yield strength and tensile elongation at various temperatures are plotted against grain size (d) and interlamellar spacing. Figures 7(a) and (b) show the plot of the room-temperature tensile elongation as functions of $d$ and $d^{-1 / 2}$, respectively. As indicated in Fig. 7(b), a linear relationship fits reasonably well between the tensile ductility and 
$\mathrm{d}^{-1 / 2}$. This relationship had also been observed for quasi-brittle materials, based on a consideration of the propagation of cracks with an average length that is the same as the grain size [13]. Note that such a relationship does not hold for the ductility at elevated temperatures, such as $800^{\circ} \mathrm{C}$.
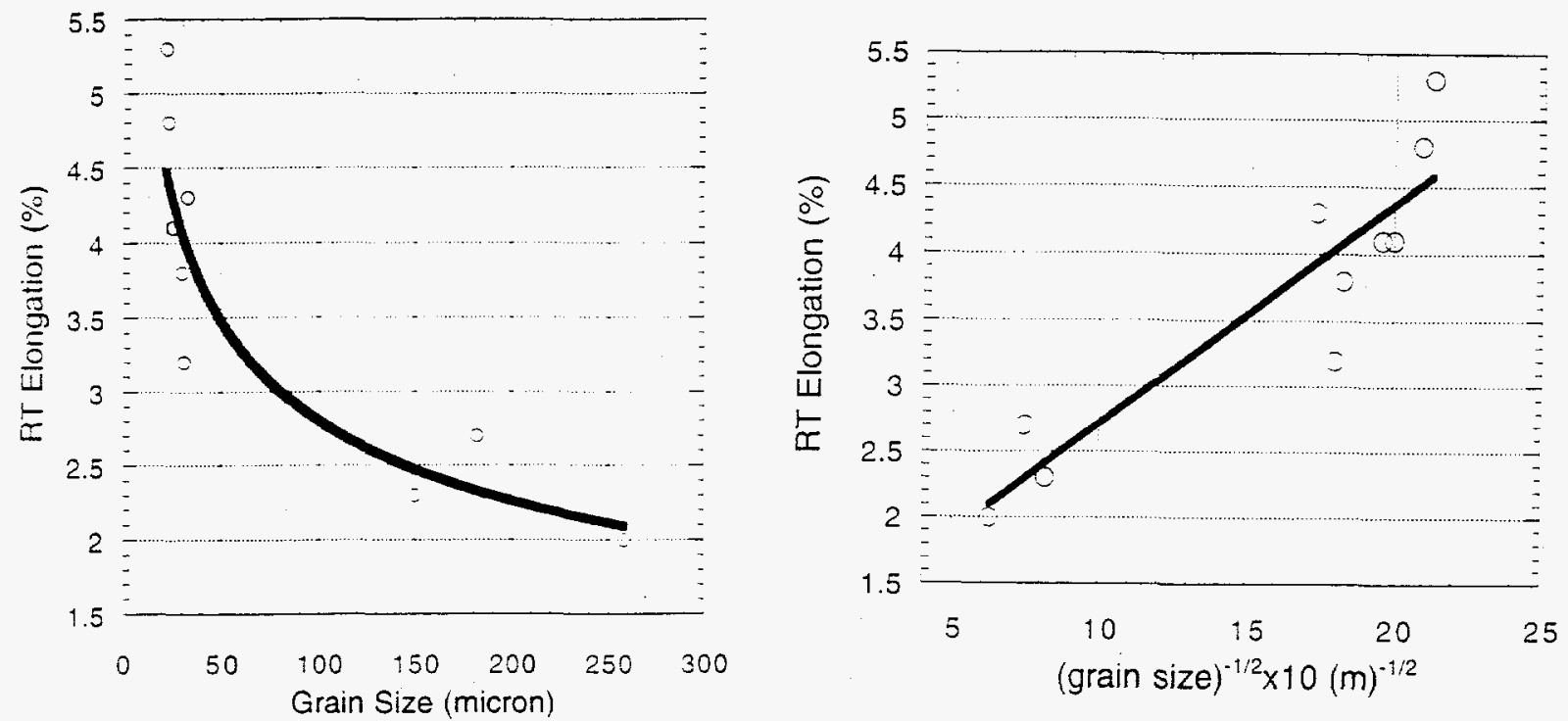

Fig. 7. Plot of room-temperature tensile elongation as a function of (a) grain size (d) and (b) $\mathrm{d}^{-1 / 2}$

The yield strength of TIA alloys at room and elevated temperatures are analyzed by the HallPetch equation based on both the grain size and the interlamellar spacing. No linear relationships exist for the grain size plot, but an excellent relationship is found for the interlamellar spacing plot, as shown in Fig. 8 for the yield strength at room temperature and $800^{\circ} \mathrm{C}$. These plots clearly indicate that the interlamellar spacing is the key parameter controlling the yield strength of these two-phase TiAl alloys. Hall-Petch relationships were observed for two-phase TiAl alloys [1,5,1416], where the yield strength at room temperature was plotted against grain size, instead of interlamellar spacing. A more detailed comparison of the values of the Hall-Petch slope obtained in this study with those reported previously will be discussed elsewhere [17].
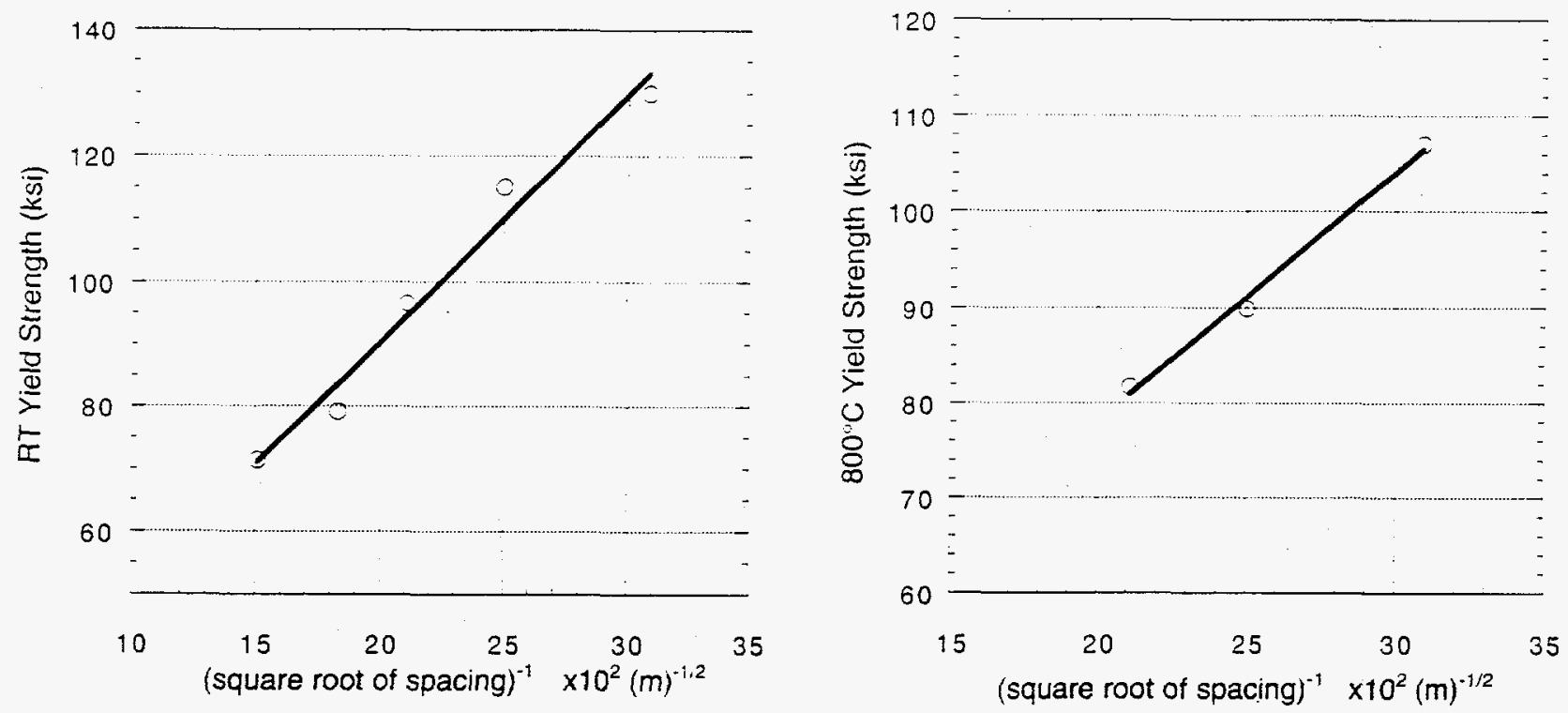

Fig. 8. Hall-Petch plot of the room temperature and $800^{\circ} \mathrm{C}$ yield strength data for TIA alloys versus interlamellar spacing 


\section{CONCLUSION}

The study of microstructures and tensile properties of two-phase TiAl with lamellar structures based on $\mathrm{Ti}-47 \mathrm{Al}-2 \mathrm{Cr}-2 \mathrm{Nb}$ leads to the following important conclusions:

1. The interlamellar spacing and grain size in the TiAl alloys with lamellar structures can be controlled by hot extrusion at temperature above $T_{\alpha}$ and subsequent heat treatment around $T_{\alpha}$.

2. The tensile ductility around $5 \%$ and strength around $900 \mathrm{MPa}$ at room temperature are obtained for the TiAl alloys with ultra-fine lamellar structures (grain size $<35 \mu \mathrm{m}$, and interlamellar spacing $0.1 \mu \mathrm{m}$ ).

3. A Hall-Petch relationship exists between the room-temperature tensile elongation and grain size, indicating that the grain size is the key parameter in controlling the ductility at room temperature. Such a relationship, however, does not hold for the elongation at elevated temperatures, such as $800^{\circ} \mathrm{C}$.

4. An excellent Hall-Petch relationship is found between the yield strength at room and elevated temperatures and the interlamellar spacing, but no such relationahip is found for the grain size. This analysis indicates that the interlamellar spacing is the key parameter in controlling the strength of these TiAl alloys with refined lamellar structures.

\section{ACKNOWLEDGMENTS}

The authors are grateful to D. S. Easton, L. Heatherly, K. S. Blakely, and C. A. Carmichael for alloy preparation and fabrication and C. G. McKamey and J. H. Schneibel for manuscipt review. Thanks are due to Pam Wenzel and Judy McKinney for manuscript preparation. This research was sponsored by the Office of Industrial Technologies, Advanced Industrial Materials Program, and the Division of Materials Science, U.S. Department of Energy, under contract DEAC05-96OR22464 with Lockheed Martin Energy Research Corporation.

\section{REFERENCES}

1. Kim, Y.-W., Trends in the Development of Gamma TiAl Alloys, Gamma Titanium Aluminides, eds. Y.-W. Kim, R. Wagner \& M. Yamaguchi, TMS, 1995, pp. 637-54.

2. Liu, C. T., Maziasz, P. J., Clemens, D. R., Schneibel, J. H., Sikka, V. K., Nieh, T. G., Wright, J. L. \& Walker, L. R., Gamma Titanium Aluminides, eds Y.-W. Kim, R. Wagner \& M. Yamaguchi, TMS, 1995, pp.679-88.

3. Huang, S. C., Structural Intermetallics, eds R. Darolia, J. Lewandowski, C. T. Liu, P. Martin, D. Miracle \& M. Nathal, TMS, Warrendale, 1993, pp. 299-307.

4. Yamaguchi, M. \& Inui, H., Structural Intermetallics, eds R. Darolia, J. Lewandowski, C. T. Liu, P. Martin, D. Miracle and M. Nathal, TMS, Warrendale, 1993, pp. 127-42. 
5. Kim, Y.-W., Effect of Microstructure on the Deformation and Fracture of Gamma TiAl Alloys, Mat. Sci. Engr., A192/193, (1995) pp. 518-33.

6. Kim, Y.-W., Wagner, R. \& Yamaguchi, M., Gamma Titanium Aluminides, TMS, 1995.

7. Huang, S. C., Metall. Trans. A., 23A (1992) 375.

8. Wang, J. N., Schwartz, A. J., Nieh, T. G., Liu, C. T., Sikka, V. K. \& Clemens, D., Gamma Titanium Aluminides, eds Y.-W. Kim, R. Wagner \& M. Yamaguchi, TMS, 1995, pp. 949-57.

9. Liu, C. T., Schneibel, J. H., Maziasz, P. J., Wright, J. L. and Easton, D. S., Intermetallics, 4 (1996) pp. 429-440.

10. Nakano, T. \& Umakoshi, Y., Intermetallics, 2 (1994) 185.

11. Ramanujan, R. V., Maziasz, P. J. \& Liu, C. T., The Thermal Stability of the Microstructure of $\gamma$-based Titanium Aluminides, Acta Metall., 44, (1996) 2611.

12. Godfrey, A. B. and Loretto, M. H., Intermetallics, 4 (1996) 47.

13. Liu, C. T., Inouye H. and Schaffhauser, A. C., Metall. Trans. 12A, (1981) pp. 993-1002.

14. Kim, Y.-W., J. Metals, 46(7) (1994) 30.

15. Chan, K. S. \& Kim, Y.-W., Acta Metall., 43 (1995) 439.

16. Kim. Y.-W., Intermetallic Compounds, eds M. Yamaguchi \& H. Fukutomi, 3rd Japan Int'l. SAMPE Symp., Chiba, Japan, Dec. 7-9, 1993, pp. 1310-17.

17. Liu, C. T., unpublished results, Nov. 1996, Oak Ridge National Laboratory, Oak Ridge, TN, 37831-6115.

\section{DISCLAIMER}

This report was prepared as an account of work sponsored by an agency of the United States Government. Neither the United States Government nor any agency thereof, nor any of their employees, makes any warranty, express or implied, or assumes any legal liability or responsibility for the accuracy, completeness, or usefulness of any information, apparatus, product, or process disclosed, or represents that its use would not infringe privately owned rights. Reference herein to any specific commercial product, process, or service by trade name, trademark, manufacturer, or otherwise does not necessarily constitute or imply its endorsement, recommendation, or favoring by the United States Government or any agency thereof. The views and opinions of authors expressed herein do not necessarily state or reflect those of the United States Government or any agency thereof. 